\title{
Debt to GDP Ratio from the Perspective of MMT
}

\author{
Yasuhito Tanaka \\ Faculty of Economics, Doshisha University, Kamigyo-ku, Kyoto, 602-8580, Japan. \\ E-mail:ochibocho@gmail.com
}

Received: November 21, 2021 Accepted: December 21, 2021 Published: December 23, 2021

doi:10.5296/bms.v13i1.19353 URL: https://doi.org/10.5296/bms.v13i1.19353

\begin{abstract}
In this note we examine the debt to GDP ratio from the perspective of MMT (Modern Monetary Theory) by a simple macroeconomic model with savings by government bonds instead of money. Mainly we will show the following results. 1) In order to maintain full employment under economic growth, the budget deficit, including interest payments on government bonds, must be positive; and if the budget deficit is smaller than this value, there will be recession with involuntary unemployment. 2) Under full employment the debt to GDP ratio approaches to a finite value over time. 3) In the underemployment case the national income is determined by the budget deficit. 4) The excessive budget deficit causes inflation. 6) In order to recover full employment from recession we need budget deficit larger than that when full employment is maintained. 5) The budget deficit, including interest payments on government bonds, equals the increase of the savings of consumers between periods (generations); and this result holds whether we have full employment or not, whether we have inflation or not. Then, the ratio of the national debt to GDP in a period is smaller than one, and even if one period constitutes of several years, the debt to GDP ratio in a year is finite.
\end{abstract}

Keywords: MMT, Budget deficit, Economic growth

JEL Classification: E12, E24

\section{Introduction}

Our several previous studies have examined Functional Finance Theory (Lerner (1943, 1944), Wray (2018)), and MMT (Modern Monetary Theory, Wray (2015), Mitchell, Wray and Watts (2019), Kelton (2020) $)^{1}$. In these studies, according to, for example, Otaki $(2005,2007$, 2009, 2015), we have examined the fiscal policy debate in several models: the static model, the overlapping generations model of perfect competition under constant returns to scale technology, the overlapping generations model of perfect competition under decreasing

\footnotetext{
${ }^{1}$ Other references for MMT are Shimakura (2019), Mochizuki (2020), Morinaga (2020), Nakano (2020) and Park (2020). These are introductory texts for MMT written in Japanese.
} 
returns to scale technology with positive profits, and an overlapping generations model of monopolistic competition (oligopoly with differentiated goods) with positive profits, with or without pay-as-you-go pensions for the older generation of consumers, with or without unemployment insurance, and with or without consumption in childhood period before the younger (working) period. In these models, we studied the problems caused by budget deficits from the perspective of functional fiscal theory and MMT, based on the microeconomic foundations of consumer and firm behavior: utility maximization for consumers under budget constraints and profit maximization for firms ${ }^{2}$. This note, on the other hand, discusses the effects of budget deficits using a very simple macroeconomic model without microeconomic foundation.

We think that the essence of MMT with respect to fiscal policy lies in the following two points.

1. "We don't need funding for fiscal spending" and 'Taxes are not a source of funding for fiscal spending".

From a macroeconomic perspective, fiscal spending serves to increase demand for goods, while taxes serve to decrease demand by reducing disposable income of consumers. In order to achieve full employment and stable growth without causing inflation, an appropriate balance between the size of fiscal spending and taxes is necessary, not the need for taxes to finance fiscal spending.

2. There is no need to pay off the national debt with taxes.

The central bank could buy up all government bonds. This may have the effect of lowering interest rates, but it will not increase people's assets or income (unless the central bank buys them at a price above face value), so it will not directly increase demand for goods, and it will not cause high inflation. If implemented during a recession, it will not cause low inflation either. Government bonds, like bank time deposits, are money in the broad sense ("liquidity in the broad sense"), and the central bank's purchase of government bonds does not increase the money supply in that sense, and thus does not cause inflation even from the standpoint of the quantity theory of money.

Mainly we will prove the following results.

1) Economic growth with full employment

In order to maintain full employment under economic growth, the budget deficit, including interest payments on government bonds, must be positive. (Proposition 1)

If the budget deficit is smaller than the value which is necessary to maintain full employment, there will be recession with involuntary unemployment. (Proposition 2)

2) Debt to GDP ratio

Under full employment with constant price the debt to GDP ratio approaches to a finite value. (Proposition 3)

3) Underemployment case

1. The real national income is determined by the budget deficit given the marginal propensity

\footnotetext{
${ }^{2}$ Please see Tanaka (2021a, 2021b, 2021c, 2021d, 2021e).
} 
to consume, the savings carried over from the previous period and tax. (Proposition 4)

2. The real national income is determined by the budget deficit given the marginal propensity to consume, the savings carried over from the previous period and the fiscal spending. (Proposition 5)

4) Inflation by the excessive budget deficit

The excessive budget deficit causes inflation. (Proposition 6)

5) Recovery from recession

In order to recover full employment from recession we need budget deficit larger than that when full employment is maintained. (Proposition 7)

The excessive budget deficit to recover recession is a short-run problem. It does not affect the long-run value of the debt to GDP ratio.

6) The budget deficit and the savings by consumers

The budget deficit, including interest payments on government bonds, equals the increase of the savings of consumers between periods (generations). (Proposition 8) Note that the budget deficit is an independent variable, and the savings as well as income are dependent variables. This result holds whether we have full employment or not, whether we have inflation or not. (Proposition 9) It implies that in any case the accumulated budget deficit at the end of each period equals the savings of consumers in that period. Then, the ratio of the national debt to GDP in a period is smaller than one, and even if one period constitutes of several years, the debt to GDP ratio in a year is finite. Also we will show that the debt to GDP ratio approaches to a finite value under full employment with inflation. In Appendix we briefly consider a case where investment is a function of the interest rate.

\section{Analyses}

\subsection{Economic Growth With Full Employment}

We consider a simple macroeconomic model without microeconomic foundation of consumers and firms. We assume that the economy grows between periods (or generations) at the rate of $\gamma-1>0$. Let $Y_{f}$ be the full employment real national income in Period 1. It increases from a period to the next period at the rate of $\gamma-1$. The price of the goods is one. The issue of inflation will be considered in a later sub-section. The consumption function in this period under full employment is

$$
C=C_{0}+\alpha\left(Y_{f}-T\right)
$$

$C$ is the real consumption. $C_{0}$ is the constant part of $C . T$ is the tax. $\alpha$ is the marginal propensity to consume. $0<\alpha<1$. The national income in this period satisfies the following equation.

$$
Y_{f}=C+I+G=C_{0}+\alpha\left(Y_{f}-T\right)+I+G .
$$

$G$ is the real government expenditure. $I$ is an investment of firms. No detailed analysis of investment is given. The savings of the consumers in this period is 


$$
(1-\alpha)\left(Y_{f}-T\right)-I
$$

We suppose that the savings are made not in money but in government bonds, which generate interest at the rate of $r$. We can assume that $C_{0}$ is financed by the savings of the previous generation consumers. Then,

$$
C_{0}=\frac{1+r}{\gamma}\left[(1-\alpha)\left(Y_{f}-T\right)-I\right]>0
$$

Investment and tax also increase at the rate of $\gamma-1$. From (1)

$$
G-T=\frac{\gamma-1-r}{\gamma}\left[(1-\alpha)\left(Y_{f}-T\right)-I\right]>0 .
$$

This is rewritten as

$$
G-T+\frac{r}{\gamma}\left[(1-\alpha)\left(Y_{f}-T\right)-I\right]=\frac{\gamma-1}{\gamma}\left[(1-\alpha)\left(Y_{f}-T\right)-I\right]
$$

The left-hand side is the budget deficit, including interest payments on government bonds. Therefore, (2) means

Proposition 1. In order to maintain full employment under economic growth, the budget deficit, including interest payments on government bonds, must be positive.

(2) also implies the following result.

Proposition 2. If the budget deficit is smaller than the value in (2), there will be recession with involuntary unemployment.

\subsection{Debt to GDP Ratio}

We assume that full employment continues to be maintained under constant price. The economy begins in Period 0 . In that period, we have $C_{0}=0$, and the budget deficit is

$$
\frac{1}{\gamma}(G-T)=\frac{1}{\gamma}\left[(1-\alpha)\left(Y_{f}-T\right)-I\right] .
$$

In Period 2 we have

$$
\gamma(G-T)+r\left[(1-\alpha)\left(Y_{f}-T\right)-I\right]=(\gamma-1)\left[(1-\alpha)\left(Y_{f}-T\right)-I\right] .
$$

Generally, in Period $n$ the budget deficit is

$$
\gamma^{n-1}(G-T)+r \gamma^{n-2}\left[(1-\alpha)\left(Y_{f}-T\right)-I\right]=\gamma^{n-2}(\gamma-1)\left[(1-\alpha)\left(Y_{f}-T\right)-I\right] .
$$

Note that $G$ and $T$ denote the fiscal spending and the tax in Period 1. The sum of the budget deficit from Period 0 to $n$ is 


$$
\begin{aligned}
& \sum_{k=1}^{n} \gamma^{k-2}(\gamma-1)\left[(1-\alpha)\left(Y_{f}-T\right)-I\right]+\frac{1}{\gamma}\left[(1-\alpha)\left(Y_{f}-T\right)-I\right] \\
& \quad=\frac{\gamma^{n}-1}{\gamma-1} \frac{\gamma-1}{\gamma}\left[(1-\alpha)\left(Y_{f}-T\right)-I\right]+\frac{1}{\gamma}\left[(1-\alpha)\left(Y_{f}-T\right)-I\right] \\
& \quad=\frac{\gamma^{n}-1}{\gamma}\left[(1-\alpha)\left(Y_{f}-T\right)-I\right]+\frac{1}{\gamma}\left[(1-\alpha)\left(Y_{f}-T\right)-I\right]
\end{aligned}
$$

Since the national income in Period $n$ is $\gamma^{n-1} Y_{f}$, the debt to GDP ratio in that period is

$$
\frac{\frac{\gamma^{n}-1}{\gamma}\left[(1-\alpha)\left(Y_{f}-T\right)-I\right]+\frac{1}{\gamma}\left[(1-\alpha)\left(Y_{f}-T\right)-I\right]}{\gamma^{n-1} Y_{f}} .
$$

When $n \rightarrow \infty$, it approaches to

$$
\frac{(1-\alpha)\left(Y_{f}-T\right)-I}{Y_{f}}
$$

This value is less than one, but not necessarily less than one if we interpret a period of time as representing multiple years; let's assume that a period of time corresponds to $m$ years, where $m$ is a natural number. Let $\tau-1$ be the growth rate over one year, and $y_{f}$ be the national income under full employment in the first year in Period 1. Then,

$$
Y_{f}=\left(1+\tau+\cdots+\tau^{m-1}\right) y_{f}=\frac{\tau^{m}-1}{\tau-1} y_{f}
$$

and

$$
\gamma Y_{f}=\tau^{m}\left(1+\tau+\cdots+\tau^{m-1}\right) y_{f}=\tau^{m} \frac{\tau^{m}-1}{\tau-1} y_{f}=\tau^{m} Y_{f}
$$

Thus,

$$
\gamma=\tau^{m}
$$

Similarly, let $t$ and $i$ be the tax and the investment in the first year in Period 1 . We have

$$
T=\frac{\tau^{m}-1}{\tau-1} t, I=\frac{\tau^{m}-1}{\tau-1} i
$$

Then, the debt to GDP ratio in the last year in a period when $n \rightarrow \infty$ approaches to

$$
\frac{(1-\alpha)\left(Y_{f}-T\right)-I}{\tau^{m-1} y_{f}}=\frac{\tau^{m}-1}{\tau^{m}-\tau^{m-1}} \frac{(1-\alpha)\left(Y_{f}-T\right)-I}{Y_{f}} .
$$

This may be larger than one, but its value is finite ${ }^{3}$. For example, if $Y_{f}=500 \mathrm{~m}, I=85 \mathrm{~m}$ $T=85 m, m=24, \alpha=0.6, \tau=1.02$, this value is about 3.1. A budget deficit of about three

\footnotetext{
${ }^{3}$ The constant part of the consumption function is zero only in the first year of Period 0 , but this does not affect the long-run value of the debt to GDP ratio.
} 


\section{Macrothink}

times GDP is a natural occurrence. We have shown the following result.

Proposition 3. Under full employment with constant price the debt to GDP ratio approaches to a finite value.

\subsection{Underemployment Case}

We assume underemployment, that is, $Y<Y_{f}$ in Period 1. In Period 0 full employment was achieved. The price of the good is one. With

$$
C_{0}=\frac{1+r}{\gamma}\left[(1-\alpha)\left(Y_{f}-\bar{T}\right)-I\right]
$$

the consumption function in Period 1 is

$$
C=\frac{1+r}{\gamma}\left[(1-\alpha)\left(Y_{f}-\bar{T}\right)-I\right]+\alpha(Y-T)
$$

In order to distinguish between the tax in Period 0 and that in Period 1, we will denote the former by $\frac{\bar{T}}{\gamma}$. The national income is

$$
Y=C+I+G=\frac{1+r}{\gamma}\left[(1-\alpha)\left(Y_{f}-\bar{T}\right)-I\right]+\alpha(Y-T)+I+G .
$$

From this

$$
(1-\alpha)(Y-T)=G-T+\frac{r}{\gamma}\left[(1-\alpha)\left(Y_{f}-\bar{T}\right)-I\right]+\frac{1}{\gamma}\left[(1-\alpha)\left(Y_{f}-\bar{T}\right)-I\right]+I,
$$

or

$$
(1-\alpha)(Y-G)=\alpha(G-T)+\frac{r}{\gamma}\left[(1-\alpha)\left(Y_{f}-\bar{T}\right)-I\right]+\frac{1}{\gamma}\left[(1-\alpha)\left(Y_{f}-\bar{T}\right)-I\right]+I
$$

Therefore,

$$
Y=\frac{G-T+\frac{r}{\gamma}\left[(1-\alpha)\left(Y_{f}-\bar{T}\right)-I\right]+\frac{1}{\gamma}\left[(1-\alpha)\left(Y_{f}-\bar{T}\right)-I\right]+I}{1-\alpha}+T
$$

or

$$
Y=\frac{\alpha(G-T)+\frac{r}{\gamma}\left[(1-\alpha)\left(Y_{f}-\bar{T}\right)-I\right]+\frac{1}{\gamma}\left[(1-\alpha)\left(Y_{f}-\bar{T}\right)-I\right]+I}{1-\alpha}+G
$$

These mean the following results.

Proposition 4. The real national income $Y$ is determined by the budget deficit, including interest payments on government bonds, $G-T+\frac{r}{\gamma}\left[(1-\alpha)\left(Y_{f}-\bar{T}\right)-I\right]$ given $\alpha, C_{0}$ and $T$.

Proposition 5. The real national income $Y$ is determined by the budget deficit, including 
interest payments on government bonds, $G-T+\frac{r}{\gamma}\left[(1-\alpha)\left(Y_{f}-\bar{T}\right)-I\right]$ given $\alpha, C_{0}$ and $G$.

\subsection{Inflation by Excessive Budget Deficit}

Let $p$ be the price of the good. Suppose that the nominal national income is $p Y_{f}$, the nominal government expenditure is $G^{\prime} . C_{0}$ and $T$ do not change, and full employment is achieved. The inflation is not predicted. Then, we have

$$
p Y_{f}=\frac{1+r}{\gamma}\left[(1-\alpha)\left(Y_{f}-T\right)-I\right]+\alpha\left(p Y_{f}-T\right)+I+G^{\prime}
$$

From this

$$
G^{\prime}-T+\frac{r}{\gamma}\left[(1-\alpha)\left(Y_{f}-T\right)-I\right]=(1-\alpha)\left(p Y_{f}-T\right)-I-\frac{1}{\gamma}\left[(1-\alpha)\left(Y_{f}-T\right)-I\right] .
$$

Comparing (2) and (4), we get

$$
G^{\prime}-T-(G-T)=(1-\alpha)(p-1) Y_{f}
$$

Thus, $p>1$ when $G^{\prime}-T>G-T$. Therefore, we have shown the following result.

Proposition 6. The excessive budget deficit causes inflation ${ }^{4}$.

\subsection{Recovery from recession}

Suppose that a recession is caused by an insufficient budget deficit in Period 0, and full employment is restored in Period 1. The price is constant at 1 . Let $\frac{1}{\gamma} \bar{Y}$ be the real national income in Period 0. Let $G^{\prime}$ and $T^{\prime}$ be the fiscal spending and the tax in Period 1.

Then, with

$$
C_{0}=\frac{1+r}{\gamma}[(1-\alpha)(\bar{Y}-T)-I]
$$

in Period 1

$$
Y_{f}=\frac{1+r}{\gamma}[(1-\alpha)(\bar{Y}-T)-I]+\alpha\left(Y_{f}-T^{\prime}\right)+I+G^{\prime}
$$

From this

$$
G^{\prime}-T^{\prime}=(1-\alpha)\left(Y_{f}-T^{\prime}\right)-I-\frac{1+r}{\gamma}[(1-\alpha)(\bar{Y}-T)-I]
$$

If full employment is achieved in Period 0, and the fiscal spending and the tax in Period 1 are $G$ and $T$, we have

$$
G-T=(1-\alpha)\left(Y_{f}-T\right)-I-\frac{1+r}{\gamma}\left[(1-\alpha)\left(Y_{f}-T\right)-I\right]
$$

If $T=T^{\prime},(5)$ and (6) mean

\footnotetext{
${ }^{4}$ A similar analysis can prove that tax cuts also lead to inflation.
} 


$$
G^{\prime}-T^{\prime}-(G-T)=\frac{1+r}{\gamma}(1-\alpha)\left(Y_{f}-\bar{Y}\right)>0 .
$$

On the other hand, if $G=G^{\prime}$, (5) and (6) mean

$$
\alpha\left[G^{\prime}-T^{\prime}-(G-T)\right]=\frac{1+r}{\gamma}(1-\alpha)\left(Y_{f}-\bar{Y}\right)>0 .
$$

(7) implies that the budget deficit when recession is recovered by an increase in the fiscal spending is larger than the budget deficit when full employment is maintained. (8) implies that the budget deficit when recession is recovered by the tax reduction is larger than the budget deficit when full employment is maintained. We have shown

Proposition 7 In order to recover full employment from recession we need budget deficit larger than that when full employment is maintained.

The excessive budget deficit to recover recession is a short-run problem. It does not affect the long-run value of the debt to GDP ratio.

\subsection{The Budget Deficit and the Savings by Consumers}

(2) also implies the following results.

Proposition 8. The budget deficit, including interest payments on government bonds, equals the increase of the savings between periods (generations).

Let us consider generally. Let $\frac{1}{\gamma} \bar{Y}$ be the actual real national income in the previous period (Period 0 ), $Y$ and $p$ be the actual real national income and the price in this period (Period 1). The savings in Period 0 is equal to

$$
(1-\alpha) \frac{1}{\gamma}(\bar{Y}-\bar{T})-\frac{1}{\gamma} I
$$

and the savings in Period 1 is

$$
(1-\alpha)(p Y-T)-I
$$

The price in Period 0 is normalized to 1 . From

$$
p Y=C_{0}+\alpha(p Y-T)+I+G,
$$

and

$$
C_{0}=(1+r) \frac{1}{\gamma}[(1-\alpha)(\bar{Y}-\bar{T})-I]
$$

the budget deficit, including interest payments on government bonds, in Period 1 is obtained as follows;

$G-T+\frac{r}{\gamma}[(1-\alpha)(\bar{Y}-\bar{T})-I]=(1-\alpha)(p Y-T)-I-\frac{1}{\gamma}[(1-\alpha)(\bar{Y}-T)-I]$.

Therefore, we obtain 


\section{Macrothink

Proposition 9. The result in Proposition 8 holds whether we have full employment or not, whether we have inflation or not.

Note that the budget deficit is an independent variable, and the savings as well as income are dependent variables. This proposition means that in any case the accumulated budget deficit at the end of each period equals the savings of consumers in that period. Then, the ratio of the national debt to GDP in a period is smaller than one, and even if one period constitutes of several years, the debt to GDP ratio in a year is finite.

\subsection{The Debt to GDP Ratio under Continued Inflation}

Finally, let us calculate the long-run value of the debt to GDP ratio under continued inflation.

Assume full employment and inflation at a constant rate $p-1>0$, and we assume that inflation is predicted. The inflation discussed in sub-section 3.1 was not predicted.

In Period 0, the nominal budget deficit is

$$
\frac{1}{p \gamma}(G-T)=\frac{1}{p \gamma}\left[(1-\alpha)\left(Y_{f}-T\right)-I\right]
$$

In Period 1, it is

$$
G-T+\frac{r}{p \gamma}\left[(1-\alpha)\left(Y_{f}-T\right)-I\right]=\frac{p \gamma-1}{p \gamma}\left[(1-\alpha)\left(Y_{f}-T\right)-I\right] .
$$

In Period 2, it is

$$
p \gamma(G-T)+r\left[(1-\alpha)\left(Y_{f}-T\right)-I\right]=(p \gamma-1)\left[(1-\alpha)\left(Y_{f}-T\right)-I\right] .
$$

Generally, in Period $n$ the nominal budget deficit is

$$
\begin{gathered}
(p \gamma)^{n-1}(G-T)+r(p \gamma)^{n-2}\left[(1-\alpha)\left(Y_{f}-T\right)-I\right] \\
=(p \gamma)^{n-2}(p \gamma-1)\left[(1-\alpha)\left(Y_{f}-T\right)-I\right] .
\end{gathered}
$$

Note that $G$ and $T$ denote the nominal fiscal spending and the nominal tax in Period 1. Since inflation is predicted, they increase at a constant rate $p \gamma$. The sum of the nominal budget deficit from Period 0 to $n$ is

$$
\begin{gathered}
\sum_{k=1}^{n}(p \gamma)^{k-2}(p \gamma-1)\left[(1-\alpha)\left(Y_{f}-T\right)-I\right]+\frac{1}{p \gamma}\left[(1-\alpha)\left(Y_{f}-T\right)-I\right] \\
=\frac{(p \gamma)^{n}-1}{p \gamma-1} \frac{p \gamma-1}{p \gamma}\left[(1-\alpha)\left(Y_{f}-T\right)-I\right]+\frac{1}{p \gamma}\left[(1-\alpha)\left(Y_{f}-T\right)-I\right] \\
=\frac{(p \gamma)^{n}-1}{p \gamma}\left[(1-\alpha)\left(Y_{f}-T\right)-I\right]+\frac{1}{p \gamma}\left[(1-\alpha)\left(Y_{f}-T\right)-I\right] .
\end{gathered}
$$

Since the national income in Period $n$ is $(p \gamma)^{n-1} Y_{f}$, the debt to GDP ratio in that period is 


$$
\frac{\frac{(p \gamma)^{n}-1}{p \gamma}\left[(1-\alpha)\left(Y_{f}-T\right)-I\right]+\frac{1}{p \gamma}\left[(1-\alpha)\left(Y_{f}-T\right)-I\right]}{(p \gamma)^{n-1} Y_{f}}
$$

When $n \rightarrow \infty$, it approaches to

$$
\frac{(1-\alpha)\left(Y_{f}-T\right)-I}{Y_{f}}
$$

This is the same as (3).

\section{Conclusion}

We have examined the debt to GDP ratio from the perspective of MMT (Modern Monetary Theory) and Functional Finance Theory by a simple macroeconomic model, and have shown that under economic growth with full employment with or without inflation the debt to GDP ratio approaches to a finite number over time even when people's savings are not in money but in government bonds. This conclusion is based on the fact that the budget deficit equals the increase in people's savings. The purpose of this note was to show that we can develop arguments based on the MMT concept by simple models without using complex models including microeconomic foundations.

\section{Appendix: The effects of interest sensitivity of investment}

We examine the effects of interest sensitivity of investment. Let the investment $I$ is written as

$$
I=I_{0}-r I_{1}, \quad\left(I_{0}>0, \quad I_{1}>0\right) .
$$

We assume that the interest rate for finance of investment equals the interest rate of the government bonds. $I_{0}$ and $I_{1}$ increase at the rate of $\gamma-1$.

(2) is rewritten as

$$
G-T+\frac{r}{\gamma}\left[(1-\alpha)\left(Y_{f}-T\right)-I_{0}+r I_{1}\right]=\frac{\gamma-1}{\gamma}\left[(1-\alpha)\left(Y_{f}-T\right)-I_{0}+r I_{1}\right] .
$$

Thus, the budget deficit which is necessary and sufficient to maintain full employment under economic growth with constant price depends on the interest rate. Similarly, (3) is rewritten as

$$
\frac{(1-\alpha)\left(Y_{f}-T\right)-I_{0}+r I_{1}}{Y_{f}}
$$

This also depends on the interest rate, but it's still finite.

\section{Acknowledgement}

We thank the editor and the reviewers for their thorough reviews and highly appreciate the comments and suggestions, which significantly contributed to improving the quality of the publication. This work was supported by JSPS KAKENHI Grant Number 18K01594 in Japan. 


\section{References}

Kelton, S. (2020). The Deficit Myth: Modern Monetary Theory and the Birth of the People's Economy. Public Affairs.

Lerner, A. P. (1943). Functional finance and the federal debt. Social Research, 10, 38-51.

Lerner, A. P. (1944). The Economics of Control: Principles of Welfare Economics. Macmillan.

Mitchell, W., Wray, L. R., \& Watts, M. (2019). Macroeconomics. Red Globe Press.

Mochizuki, S. (2020). A book understanding MMT (in Japanese, MMT ga yokuwakaru hon). Shuwa System.

Morinaga, K. (2020). MMT will save Japan (in Japanese, MMT ga nihon wo sukuu). Takarajimasha.

Nakano, A. (2020). A book to understand the key points of MMT (in Japanese, MMT no pointo ga yokuwakaru hon), Shuwa System.

Otaki, M. (2007). The dynamically extended Keynesian cross and the welfare-improving fiscal policy. Economics Letters, 96, 23-29. https://doi.org/10.1016/j.econlet.2006.12.005

Otaki, M. (2009). A welfare economics foundation for the full-employment policy. Economics Letters, 102, 1-3. https://doi.org/10.1016/j.econlet.2008.08.003

Otaki, M. (2015). Keynesian Economics and Price Theory: Re-orientation of a Theory of Monetary Economy. Springer. https://doi.org/10.1007/978-4-431-55345-8

Park, S. (2020). The fallacy of fiscal collapse (in Japanese, Zaisei hatanron no ayamari). Seitosha.

Shimakura, G. (2019) What is MMT? (in Japanese, MMT towa nanika), Kadokawa Shinsho.

Tanaka, Y. (2021a). Very simple mathematical model of MMT (Modern Monetary Theory), Business and Economic Research, 11(3), 78-87. https://doi.org/10.5296/ber.v11i3.18983

Tanaka, Y. (2021b). An elementary mathematical model for MMT (Modern Monetary Theory), Research in Applied Economics, 13(3), 1-20.

https://doi.org/10.5296/ber.v11i3.18983

Tanaka, Y. (2021c). Mathematical model of MMT with profit return under monopolistic competition, Journal of Social Science Studies, 8(2), 65-87.

https://doi.org/10.5296/jsss.v8i2.19073

Tanaka, Y. (2021d). A brief rationale for MMT arguments, Issues in Social Science, 9(2), 1-8. https://doi.org/10.5296/iss.v9i2.19160

Tanaka, Y. (2021e). A Mathematical Model of MMT (Modern Monetary Theory) with Profit Return, Business and Economic Research, 11(4), 39-55.

https://doi.org/10.5296/ber.v11i4.19142 


\section{Macrothink}

Wray, L. R. (2015). Modern Money Theory: A Primer on Macroeconomics for Sovereign Monetary Systems (2nd ed.). Palgrave Macmillan.

Wray, L. R. (2018). A comparison of the evolution of the positions of Hyman Minsky and Abba Lerner, Levy Economics Institute Working Paper No. 900.

\section{Copyright}

Copyright for this article is retained by the author(s), with first publication rights granted to the journal.

This is an open-access article distributed under the terms and conditions of the Creative Commons Attribution license (http://creativecommons.org/licenses/by/4.0/). 